\title{
A DISGUSSION OF ONE KUSHANO-SASANIAN SILVER PLATE AND RELATION TO GANDHARAN ART
}

\author{
Katsumi TANABE*
}

\section{Introductory Remarks}

Relics known as Sasanian silver plates include some which were produced in locales other than the Sasanian empire as well as some produced in the postSasanian or Early Islamic periods. Many of those plates were made in Central Asia. Of the category of Central Asian "Sasanian Silver", the Sogdian and Ephthalite (Indian) groups ${ }^{(1)}$ are singled out for unique classification. All the rest compose the so-called Bactrian, (2) Tocharian, Choresmian or KushanoSasanian silver plates. In this paper I attempt to clarify the place of origin of one of the group of relics known as Sasanian silver plates by comparing this with several lion sculptures produced in the Gandhara and Kapisi regions almost contemporaneously with Kushano-Sasanian silver plates.

\section{Kushano-Sasanian or Eastern Iranian Silver Plates}

In 1967 V. G. Lukonin published an article treating the classification of Kushano-Sasanian coins; in this article he touched on the possibility of KushanoSasanian origin of one silver plate (Fig. 1) $)^{(3)}$ of the British Museum's collection. He compared the figure of Mithra depicted in this investiture scene with a similar investing Mithra on the reverse of a bronze coin issued by the KushanoSasanian King, Ardashir (Fig. 2)(4). On the basis of the similarity of these two figures and the arrangement of various figures in this plate quite atypical among royal Sasanian plates, he suggested that this plate may have been produced in the Kushano-Sasanian kingdom in the fourth century. This plate is commonly believed to have been acquired in Rawalpindi, a provenance which would, if confirmed, support his conclusion. In a subsequent article, P. O.

* Director of Research Department, The Ancient Orient Museum, Tokyo.

Vol. XXV 1989 


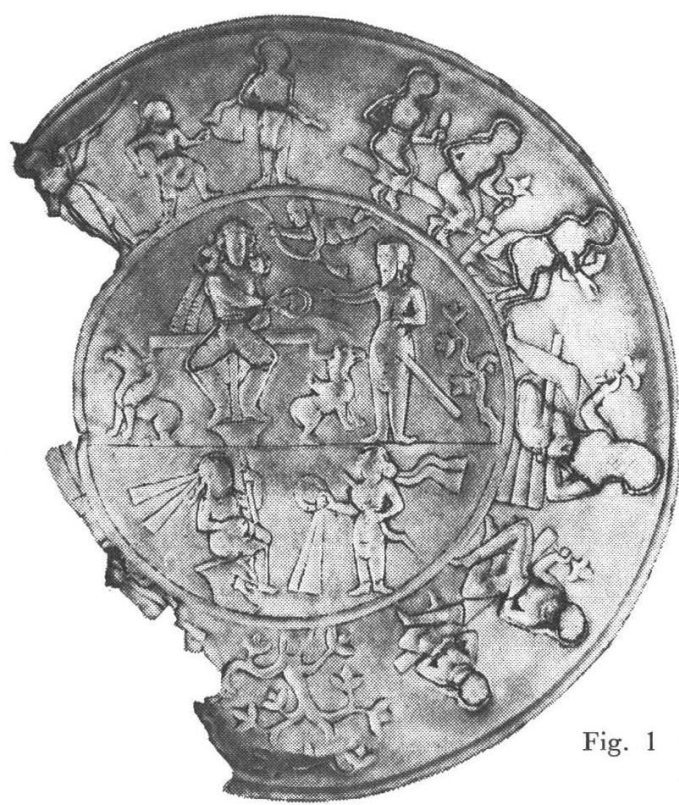

Fig. 1 Silver plate, the British Museum,

P. O. Harper 1981, Fig. 35

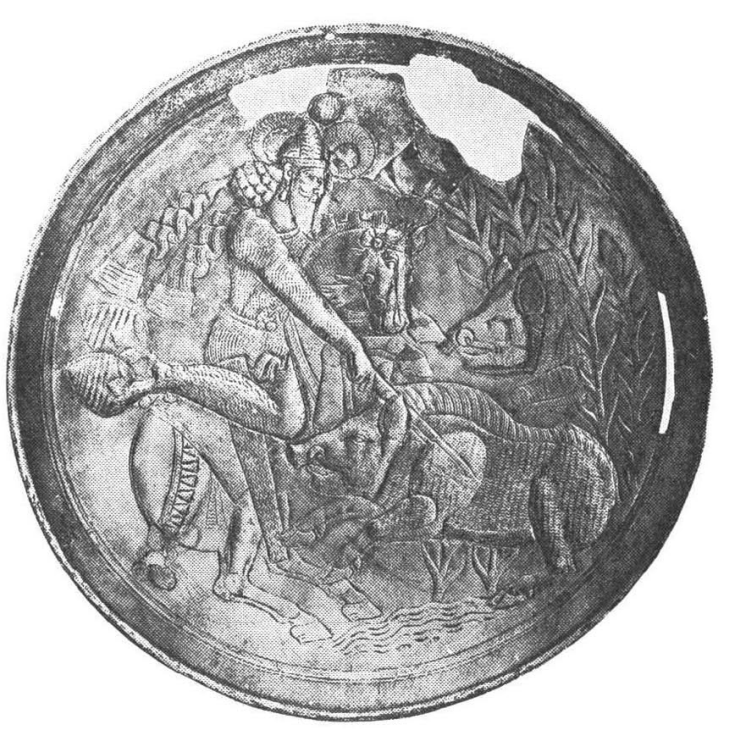

Fig. 3 Silver plate, State Hermitage Museum, Smirnov Vostochnoe Serebro, 1909, Pl. XXV

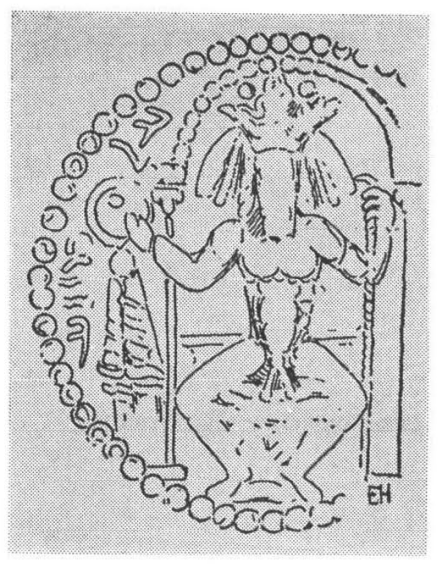

Fig. 2 Enthroned god, Herzfeld 1930, Fig. 21

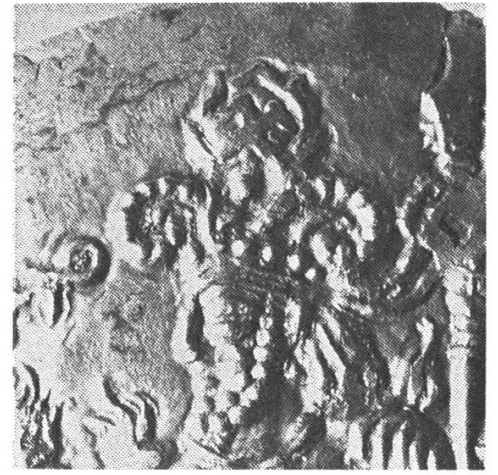

Fig. 4 Detail of Bahram (II), gold coin (obv.) private collection, Kamakura 
Harper cited Lukonin's interpretation, and agreed that this plate from the fourth century A. D. should be considered a Kushano-Sasanian work. ${ }^{(5)}$ I aslo agree that this plate was produced in the Kushano-Sasanian kingdom, but take exception to Lukonin's theory of its relation to the rock-cut investiture scene ${ }^{(6)}$ of Ardashir II (379-383) at Taq-i Bustan.

In the same article, Lukonin also discussed another silver plate which depicts a royal boar hunt (Fig. 3). In this plate the hunting king wears a crown composed of two ram's horns, a type of the crown identical with those (Fig. 4)(7) known to have been worn by the Kushano-Sasanian king, Bahram (II). According to Lukonin, this type of crown should be classified as type $f$ KushanoSasanian crown. This would suggest that this plate was probably produced on Bahram's imperial orders. However, Lukonin did not mention definitely about the place of production of this plate, but simply compared this plate with another silver plate of the British Museum's collection (Fig. 5), said to represent Shahpur II's deer hunt. Lukonin then mentioned that these two plates resembled one another and therefore might have been produced by the same artist. $\mathrm{He}$ associated the ram-horned headdress with Bahram, son of Bahram IV (388-399), whom Lukonin assumes to have been the Kushano-Sasanian king from 388 to $389 . .^{(8)}$ I cannot agree with assigning the piece such a late date of origin, with the conjectural attribution of the work to a hitherto-unknown son of Bahram IV. In my opinion, Lukonin was too much influenced by his own chronology(9) of the Kushano-Sasanian dynasty, which he estimated as beginning around the middle of the fourth century A. D. Lukonin attempted to show that the Kushano-Sasanian kings were almost contemporaneous with the Sasanian Kings of Kings such as Shahpur II (309-379), Ardashir II, Shahpur III (383388) and Bahram IV, i. e., that they reigned between the fourth and early fifth centuries.

With regard to the dating of this plate, I. A. Orbeli and K. V. Trever(10) had earlier assumed that it represented a hunt conducted by Bahram V (420438). Therefore, Lukonin might have been influenced by his predecessors' dating. Furthermore, there is also a literary basis for dating this plate to the fourth century. According to Ammianus Marcellinus, ${ }^{(11)}$ Shahpur II (309379) besieged Amida during the winter of 359 (360) A. D. He appeared wearing a ram-headed helmet. With regard to this ram's head, A. D. H. Bivar(12) identified this Sasanian king as Bahram (II), king of the Kushano-Sasanian dynasty, rather than as Shahpur II. However, Ch. Brunner, R. Göbl and M. L. 


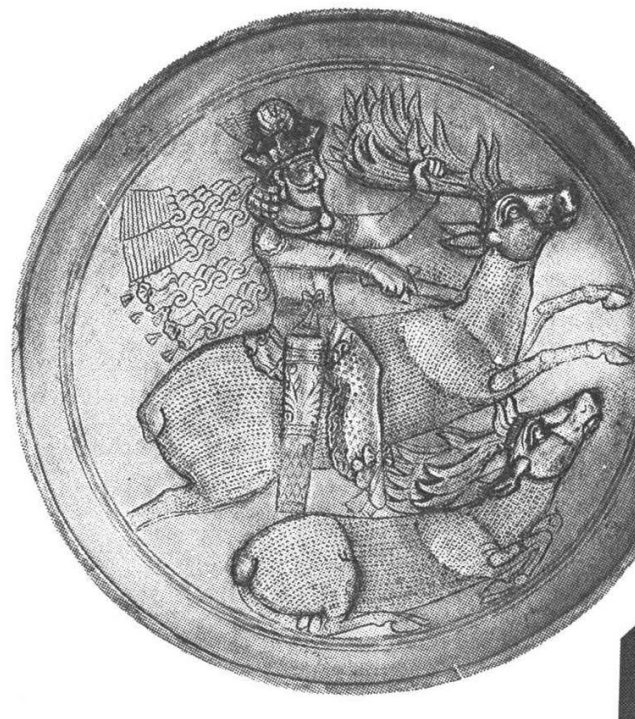

Fig. 5 Silver plate, the British Museum, Harper 1981

Pl. 13.

Fig. 6 Silver plate, Grenet 1983, Pl. I
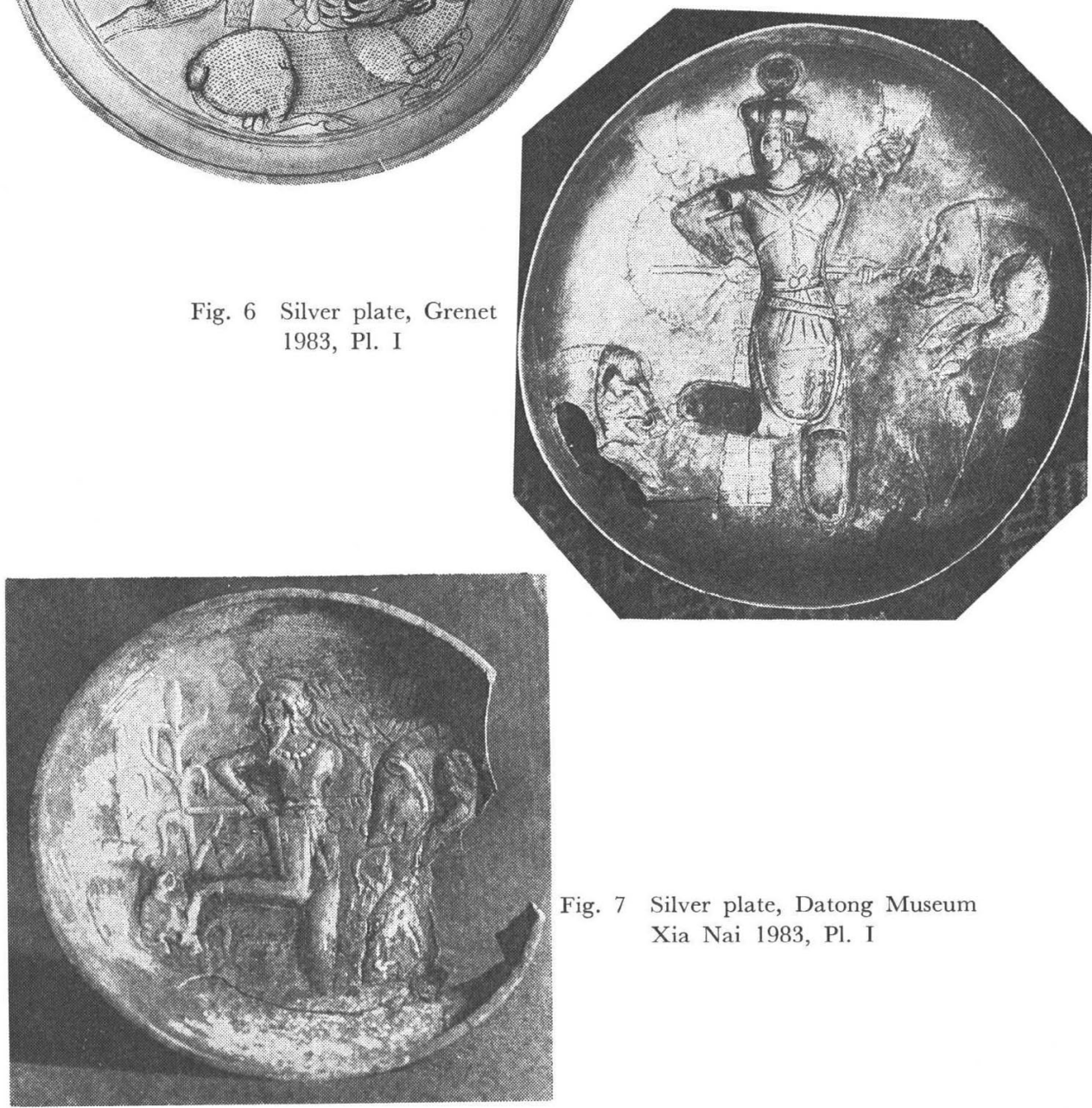

Fig. 7 Silver plate, Datong Museum Xia Nai 1983, Pl. I 
Carter(13) rejected Bivar's interpretation and maintained that the Sasanian king concerned was Shahpur II as Ammianus Marcellinus recorded. Furthermore, R. Ghirshman(14) regarded this plate as contemporary with the fourth century Shahpur II, and suggested that the ram-headed prince might represent the son of Shahpur II. Then this horned prince would probably be the future Shahpur III who is represented together with his father Shahpur II in the rock-cut relief at Taq-i Bustan.(15) Ghirshman's interpretation is the result of a study of Shahpur II's campaign of the Kushan East, which he developed in his Les Chionites-Hephthalites. ${ }^{(16)}$

However, with regard to Kushano-Sasanian chronology, the period proposed by E. Herzfeld and others, ${ }^{(17)}$ that is, the third to fourth century is more plausible. Herzfeld identified the prince with horned headdress of the boar hunt plate with the Kushano-Sasanian king Bahram (the future Bahram I, 273-276). This identification was later accepted by L. Bachhofer(18) and K. Erdmann. (19) Therefore, we should not associate the royal boar hunt (Fig. 3) with Shahpur II's deer hunt (Fig. 5), but should attribute it to Bahram, Kushano-Sasanian king. The fact that there is no Sasanian king whose crown is decorated with ram's horns(20) further supports this attribution. This type of crown is also worn by the standing king represented on both gold (Fig. 4) and bronze coins issued by Bahram (II) during the Kushano-Sasanian dynasty. Therefore, we can assume that this plate is of Kushano-Sasanian origin.

While P. O. Harper(21) theorized that this plate was actually made in the Kushan East, I would suggest that it originated in northern Afghanistan or Bactria of the third or early fourth centuries.

I have shown two Kushano-Sasanian silver plates but I would now like to show a few more recently-discovered Kushano-Sasanian plates in order to compare these finds with the unique plate representing a king with ram-horned headdress (Fig. 3). However, I would like to point out in advance a few iconographical and stylistic peculiarities of the hunting scene depicted in this unique plate.

First, the irregular representation of one of the two boars certainly deserves mention. The body of the boar on the right is incompletely drawn, with only its protome visible. The rest of its body seems to be hidden behind the reeds from which both boars are shown emerging. It certainly appears, as Harper (22) has already observed, that the reeds are cleverly used to mask the hind-quarters of the second (right) boar, because there is not enough room to represent both boars 
in their entirety. However, the part of the body which contacts the reeds could have been included but, in fact is not. A satisfactory explanation for this omission has not as yet been offered, but the most important fact is that the omission of the hind-quarters of the second boar is rendered intentionally. This kind of rendering of games is quite exceptional among the hunting scenes of the Sasanian silver plates ${ }^{(23)}$ and as Negro Ponzi( ${ }^{(24)}$ observed, its composition appears contracted in the small field, as if the subject had been reduced from a broader scene (the horse and the boar are superimposed in a clumsy way, which sharply contrasts with the sensitivity and preciseness in rendering).

Next the unique positioning of the hunter's right leg must be mentioned. In Sasanian silver plates, equestrian hunter's legs are, except for a few cases, ${ }^{(25)}$ rendered vertically. However, the right leg of the hunter in this scene is bent sharply up at the knee. The reason for this unusual detail is as Harper ${ }^{(26)}$ has suggested, that the maker of this plate needed to raise the lower part of leg out of the reach of the charging boar.

In regard to the plate's technique, P. Meyers ${ }^{(27)}$ observed that it was not formed from a single piece of silver, but that several added pieces had been crimped into place in order to allow certain important parts of the design to stand out in high relief.

Several other characteristics of the plate are unusual, and the most notable of these is hair style. The hair is rendered in many-armed hair whorls to use Harper's phrase. (28) This style is peculiar to various portraits of Bahram I $(273-276)^{(29)}$ and Bahram II $(276-293)^{(30)}$ and to the representation of Anahi$\operatorname{tah}^{(31)}$ in the relief of Narseh (293-303) at Naqsh-i Rustam. The hair style of Shahpur I (224-271)(32) is in some cases similar to that, but those ${ }^{(33)}$ of Shahpur II (309-379), Shahpur III (383-388) and Ardashir II (379-383) are all different from the style shown in this plate. Therefore, judging from the detail of the hair style, it seems reasonable to conclude that this plate was made during the latter part of the third century. The representation of Anahitah includes a similar hair style, but Narseh's hair style is notably different. ${ }^{(34)}$ This suggests that in the early fourth century the Sasanian king's hair was not represented by many-armed whorls. Though it is possible that this style survived throughout part of the fourth century, it had surely disappeared by the 380's, as is evidenced by the style of hair depicted in representations of Shahpur II, Ardashir II and Shahpur III in the Taq-i Bustan reliefs.

Now we should examine two silver plates recently discovered. The 
report of one of these was published by F. Grenet ${ }^{(35)}$ and the other, excavated in China, was published by Ma Yuji, Xia Nai, and Ma Yong.(36) The first example (Fig. 6) depicts a royal boar hunt. Although the king shown in the Hermitage plate (Fig. 3) is on horseback, the hunter in this plate is standing on a field. According to Grenet's iconographical analysis, this hunter is identifiable as Ardashir II and this plate was probably made by an artist of the Sasanian official workshop. His analysis and comparative study are quite detailed but the identification of the hunter as Ardashir II is not tenable given the type of crown he is shown wearing and stylistic details in his ribbon-diadems compared with those of the portrait of Ardashir II sculpted at Taq-i Bustan. ${ }^{(37)}$ However, the distinctive rounded shape of the lower part of the caftan worn by this hunter is identical with those of Shahpur II (after 363 A. D.), Ardashir II and Shahpur III of Taq-i Bustan reliefs. Therefore, the date of the production of this plate seems to be late fourth century.

Another is the positioning of his left leg. It is rendered with knee bent as is the case of the equestrian hunter above mentioned (Fig. 3). Although this kind of rendering is sensible in a case of an equestrian hunter with a charging boar before him (Fig. 3), it does not make sense when the hunter is standing and being charged by a boar from behind. This unusual detail can be best explained by its being considered a mechanical copy of an equestrian hunter with the right knee pulled high up.

Next the unusual details in the depiction of the two boars should be mentioned. The two boars are not presented, but rather, only their protome is rendered. All the figures fit within a circular frame, as is the case with the Hermitage plate (Fig. 3). However, there is no overlapping between the picture of the boars and the reeds. The boars' protomes emerge directly from out of the circular frame. Furthermore, The boars are not shown emerging from the same direction but from opposite sides. Most of the royal Sasanian plates show two animals advancing from the same direction, and the Hermitage plate (Fig. 3), too, follows this scheme. Thus if it is compared with those plates, this plate's rendering of two animals is unique and suggests a more developed or mechanical arrangement of the games than does the Hermitage plate, which is more faithful to the same-direction orientation of most royal Sasanian plates.

In conclusion, we may relate this plate to the Hermitage plate (Fig. 3) on the basis of the same bent knee and the representation of the boars' protomes. 
Next we should examine the plate (Fig. 7) excavated from the tomb of Feng Hetu (封和突) of the Northern Wei Dynasty (北魏). This tomb was found near Datong (大同) and contains a funerary stele of Feng Hetu. According to accounts of his personal history, Feng Hetu was born in 438 and died in 501.(38) Therefore, this plate must have been made earlier than 501 A. D. This plate, part of which is lost, shows nearly the same composition as the Kabul plate (Fig. 6). In the center of the drawing stands a royal hunter holding a spear. His posture is reminiscent of the hunter shown in the Kabul plate (Fig. 6), who is armed with a dagger and a sword. Unfortunately the foremost of the two boars advancing from the right is not well preserved. Therefore it is not clear whether, originally, this boar was presented in its entirety, or if, like the other two boars, is depicted in only its forepart. In any case, the partial representation of animals is one of the characterizing features of this plate. Large, realistic reeds, similar to those of the Hermitage plate (Fig. 3) are also shown. The bent right knee is similar to that in the Kabul plate (Fig. 6). Therefore, the composition of this hunting scene is fundamentally the same as the Kabul plate's composition. The notable difference is in the clothes, ornaments and headdress worn by the hunter. He lacks the table ronde type caftan and is not decorated with apezac (breast-band). He does not wear a typical Sasanian crown, but seems to put on something like helmet decorated with pearls along its lower hem. Furthermore, there is no so-called Sasanian corymbos on his head. Instead he seems to wear a large bulbous ornament (or ornaments) (39) on his helmeted head. This style of headdress reminds us of that of the Royal Sasanian princes ${ }^{(40)}$ of the third century, because both are not crown nor headdress of the Sasanian King of Kings. And his long pointed beard resembles that shown in the Hermitage plate (Fig. 3).

From a stylistic viewpoint, this plate is more akin to that of the horned prince's hunt (Fig. 3) than that of the Kabul plate. It seems to be of earlier production than the Kabul plate. However, the illustrations of this plate published in WENWU are not good at all, and so it is very difficult to grasp all the details with any certainty.

In addition to these plates, I should mention the discovery of a unique silver bowl quite recently reported by P. O. Harper (1989).(41) Around the outside of the bowl runs a royal hunting scene similar to Sasanian royal hunts. According to Harper's stylistic and iconographic analyses, this bowl might have been produced after the reign of Shahpur III (383-388), in the Kushano- 


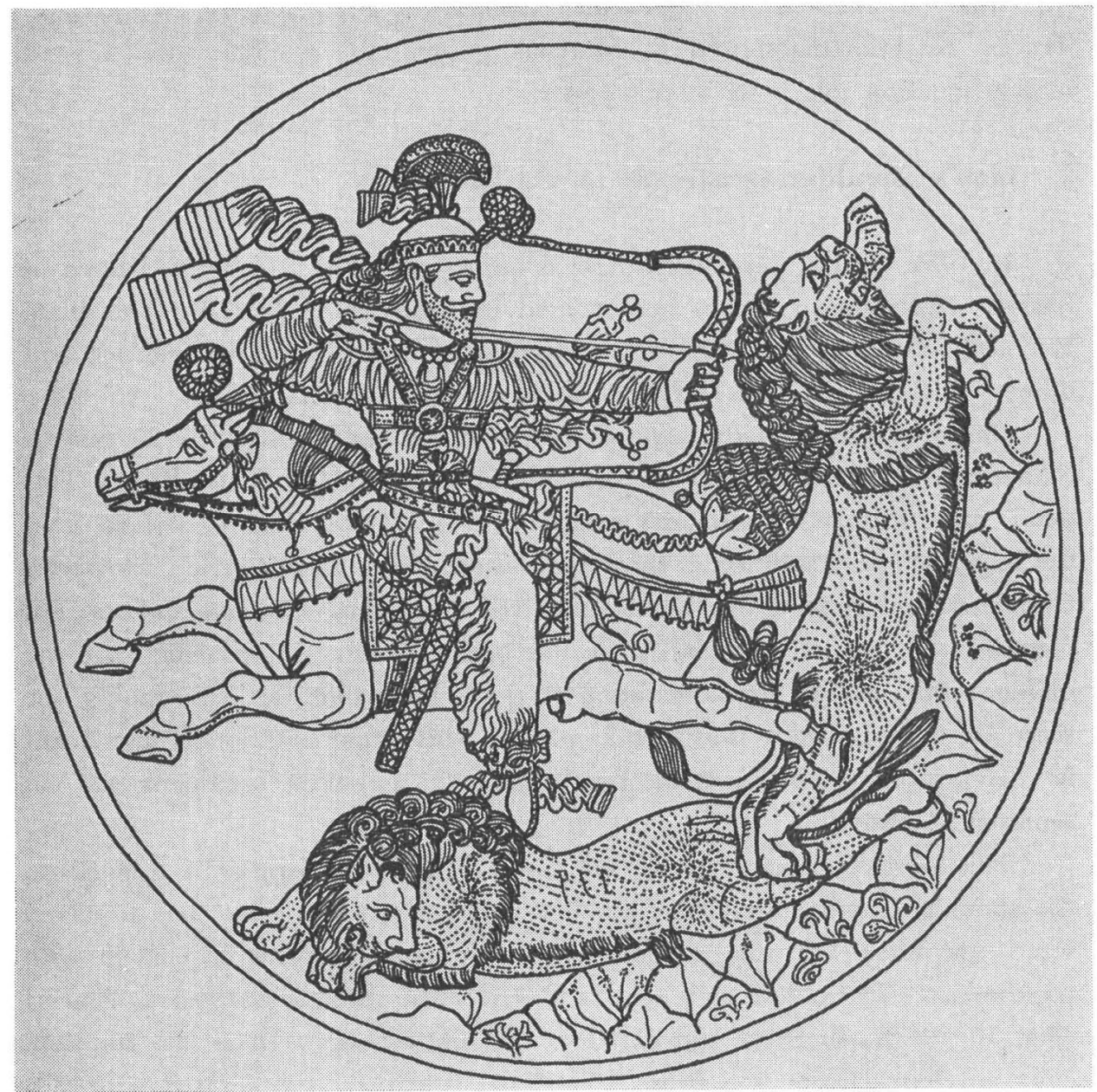

Fig. 8 Silver plate, Musee Iran Bastan (drawing by A. Hori) 
Sasanian territory. So while she suggests that this bowl may be included into the Kushano-Sasanian toreutics, yet its shape and design remain distinct from those of the Kushano-Sasanian plates I have earlier discussed. I would suggest that this bowl should be considered, rather, linked to the so-called "Bactrian" or Kushan and Ephthalite silver bowls already discussed by K. V. Trever, K. Weitzmann and B. Marshak quoted above. Therefore, I need merely mention this bowl in this paper.

\section{Lion's Shoulder Ornament in the Sari Plate}

In 1954, a silver plate with a royal hunt motif (Fig. 8) was discovered in Sari,(42) Mazandaran and is now housed in Musee Iran Bastan. This plate has been dated to the third or early fourth century by P. O. Harper and others. ${ }^{(43)}$ I believe that Harper's dating is quite reasonable.

One of the most unique characteristics of this hunting scene is the pointillé rendering of two large "shoulder" ornaments on the bodies of two lions. This detail drew Roman Ghirshman's attention;(44) his theory that it derived from the shoulder ornamentation of the Near Eastern lion is unassailable. However, Ghirshman interpreted this motif exclusively as a solar emblem and did not mention the fact of irregularity of the ornamentation's appearing. In my opinion, this unusual ornamentation is quite important for determining the place of production of this unique plate. This ornamentation is significant for two reasons: each lion wears two ornaments; and these ornaments are not represented exactly.

This kind of ornamentation (Fig. 9) ${ }^{(45)}$ of lions was originally applied on the shoulder alone and not on the buttocks. However, there are preserved some exceptional lion images, on which the ornamentation is applied in both these areas. The oldest such relic is a Syro-Hittite lion excavated at Zinrilri (Fig. 10), ${ }^{(46)}$ North Syria and dated to the ninth century B. C. In addition, a second Syro-Hittite lion from Aslan-Tash (Fig. 11) is decorated with two ornaments which appear on the shoulder. If these two examples are compared with the two sitting lions at the Lion Gate of Bogazköy (Pl. 1-a, b) on each of which only one shoulder ornament appears, it seems that the Syro-Hittite sculptors did not understand exactly what the shoulder ornament meant.

A similar misunderstanding can be seen on a fragment of gold pectoral unearthed at Ziwiyé in Kurdistan, Iran. A lion-griffin (Fig. 12) is produced 


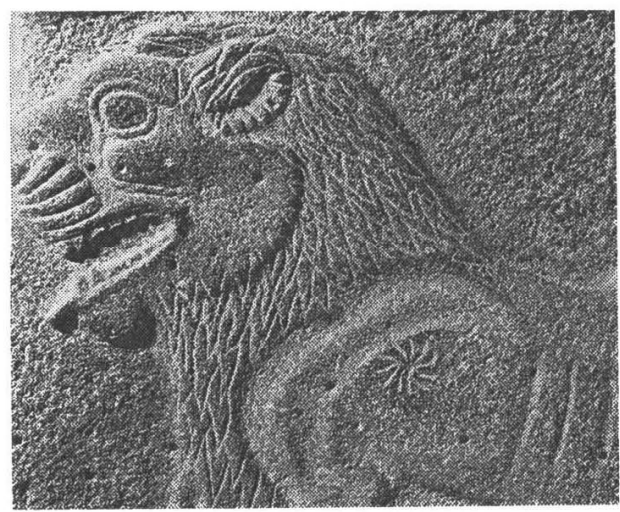

Fig. 9 Lion of Beth Shean, B. C. 14 c., Israel, Metropolitan Museum of Art, 1986, Pl. 44.

Fig. 10 Syro-Hittite lion, Zinrilri, Archaeological Museum, Istanbul, Goodenough 1958, Fig. 37

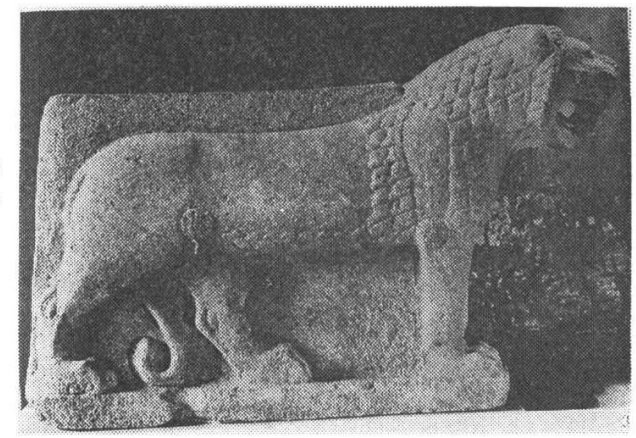

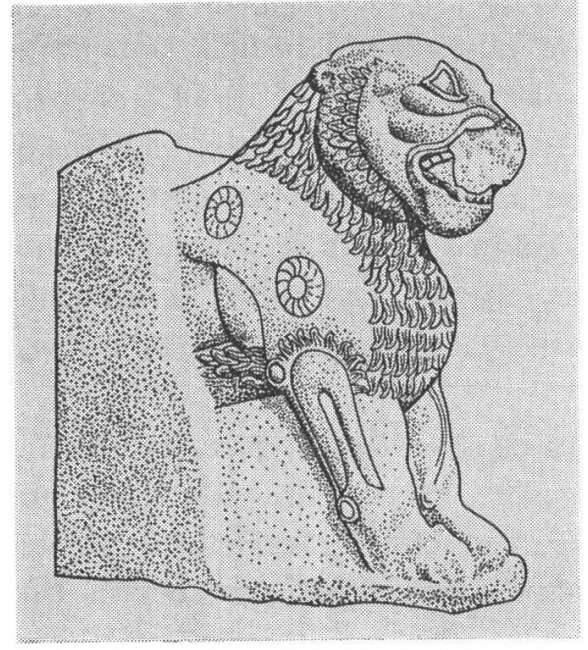

Fig. 11 Syro-Hittite lion, Aslan-Tash, Aleppo Museum, Kantor 1947, Fig. 6-A

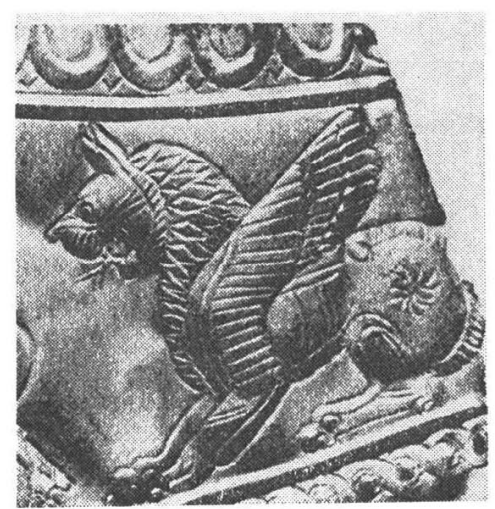

Fig. 12 Lion-griffin, Ziwiyé, L. Vanden Berghe 1959, Fig. 140-a 
by repoussé work on this gold plaque. ${ }^{(47)}$ On his buttocks is a shoulder ornament. The shoulder ornaments of Assyrian lions ${ }^{(48)}$ can be classified into two distinct types. One type is dated to the reign of Assurnasirpal II (883-859 B. C.): one shoulder ornament is depicted on the shoulder (Fig. 13). The other type is seen in the reliefs of Assurbanipal (661-631 B. C., Fig. 14): the shoulder ornament is depicted in the maned neck. According to the real whorl on the young lion's neck, ${ }^{(49)}$ the latter example is correct. Therefore, even in Assyria where royal lion hunts were extremely commonplace, and so lion images in palatial reliefs showed a high degree of realism, there was already a certain misunderstanding of the place of shoulder ornament (whorl of hair). In view of these erroneous representations, it seems completely natural to see similar mistakes in later periods ${ }^{(50)}$ when Near Eastern lions would have become far scarce and far less likely to be available to the artist for observation. One such erroneous rendering appears on a Sasanian plate (Fig. 8).

The only Sasanian silver ware which depicts a lion decorated with the shoulder ornament is the Sari plate.(51) "Sasanian" lions bearing the shoulder ornament are found only on those several silver plates dating from the postSasanian period.(52) These post-Sasanian lion images are all nearly contemporary with Sogdian lions (seventh and eighth centuries). ${ }^{(53)}$ Some of the Sogdian lions are decorated accurately with a single shoulder ornament (Fig. 15). Therefore the shoulder ornaments of lions in the Sari plate are exceptional as far as the Sasanian silver plates are concerned. Shoulder ornaments on the shoulder and the buttock are seen on both a lion and a bull depicted on a silver plate unearthed from Komarobo(54) (one on the shoulder, while the other on the buttock). Further a silver plate unearthed from Robo, ${ }^{(55)}$ in Russian Azerbaidjan shows a Sasanian ram decorated with two shoulder ornaments (on the shoulder and buttock). This ornament was regarded by Khalilov and Koshkarly as a rosette symbolizing the sun following Darkevich's view, but this remains open to strong argument.

In any case, the shoulder ornaments depicted on post-Sasanian silver need not be taken into consideration in this paper, for the Sari plate was produced several hundred years earlier. Post-Sasanian shoulder ornaments should be treated rather in connection with lion's shoulder ornaments seen in Islamic textiles and bronzes. ${ }^{(56)}$

Lastly I will mention a concrete example of the shoulder ornament of the Royal Sasanian lion images. This is attested by the present author on one of 


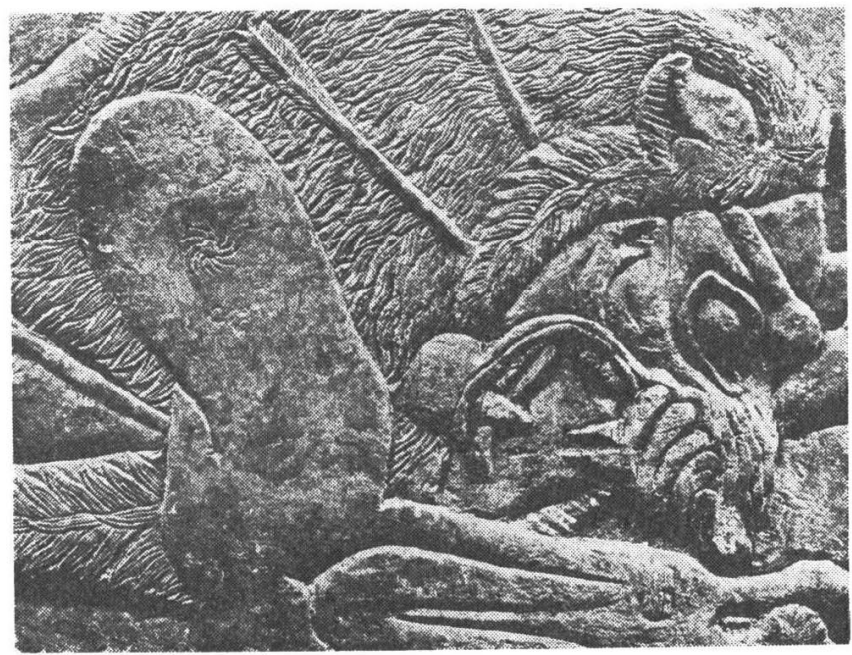

Fig. 13 Assyrian lion, the British Museum, Lorenzi 1980, Pl. $17 \mathrm{c}$

Fig. 14 Assyrian lion, the British Museum, Barnett/Lorenzi 1975, Pl. 130
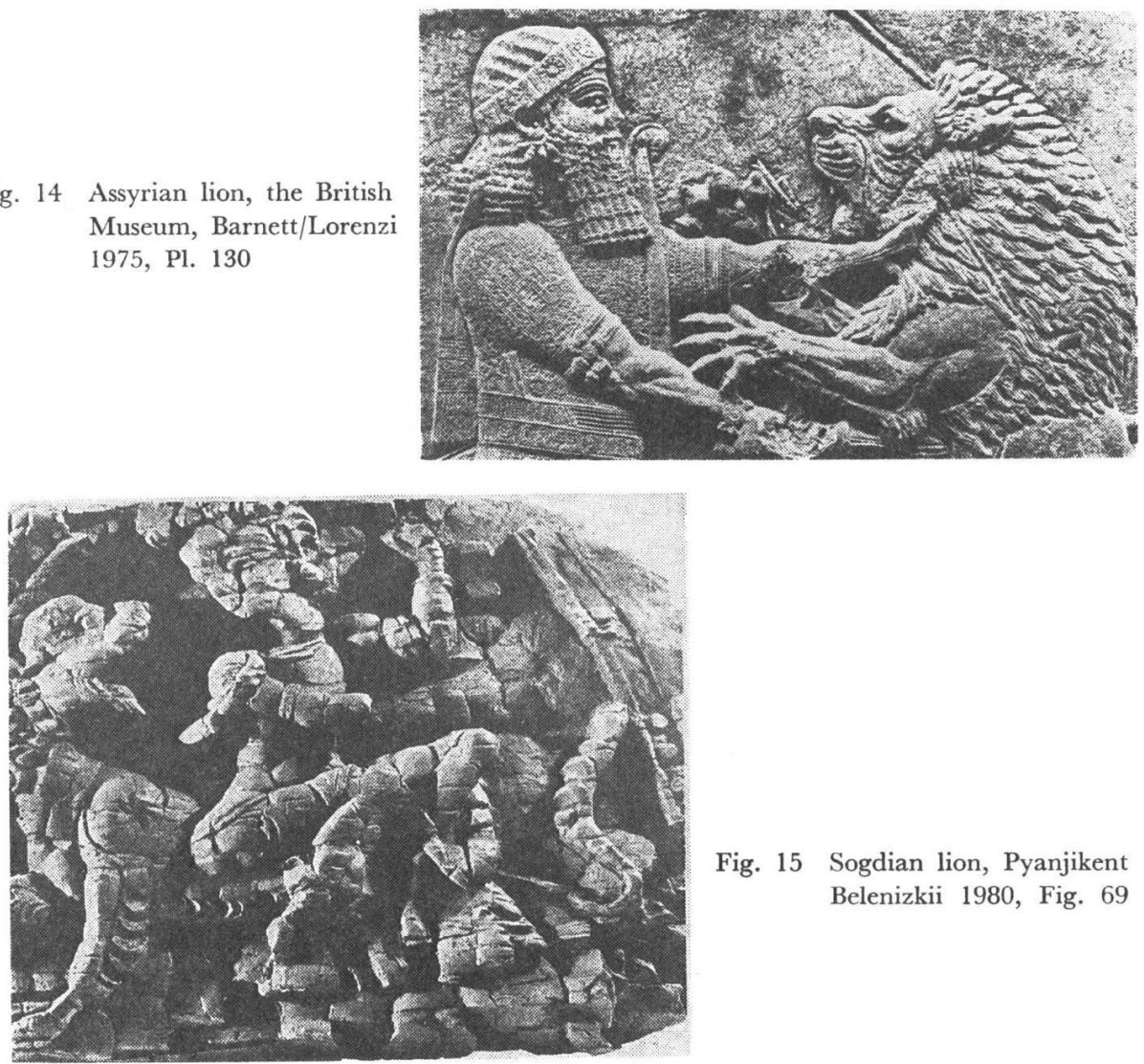

Fig. 15 Sogdian lion, Pyanjikent Belenizkii 1980, Fig. 69

Vol. XXV 1989 


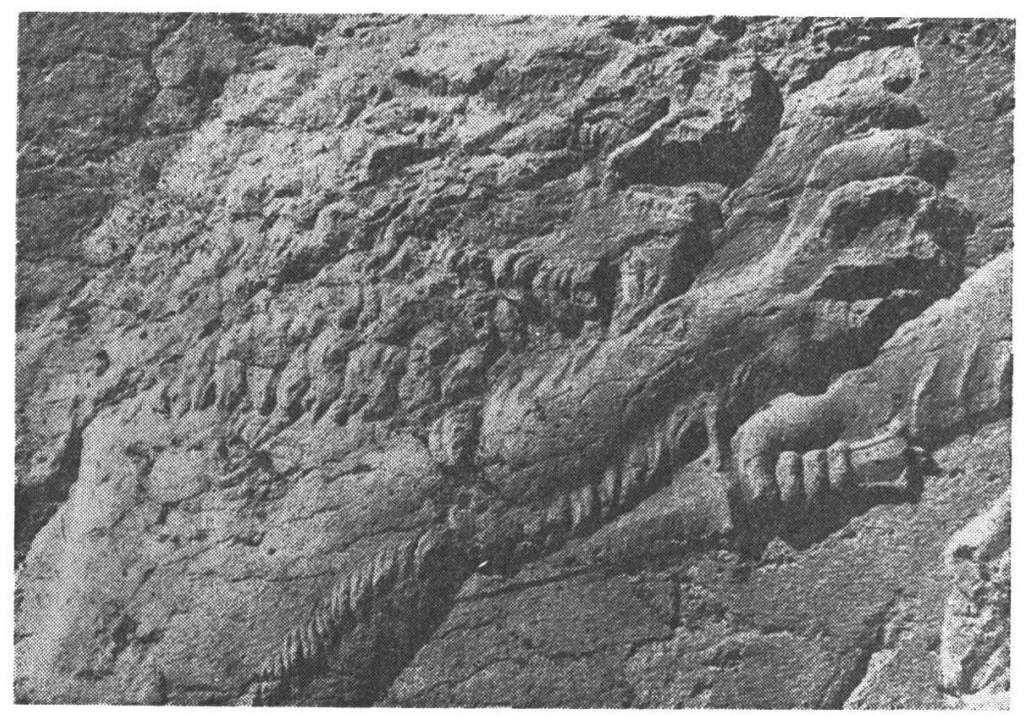

Fig. 16 Lion of Sar Mašhad relief

Trümpelmann 1975, Pl. 2

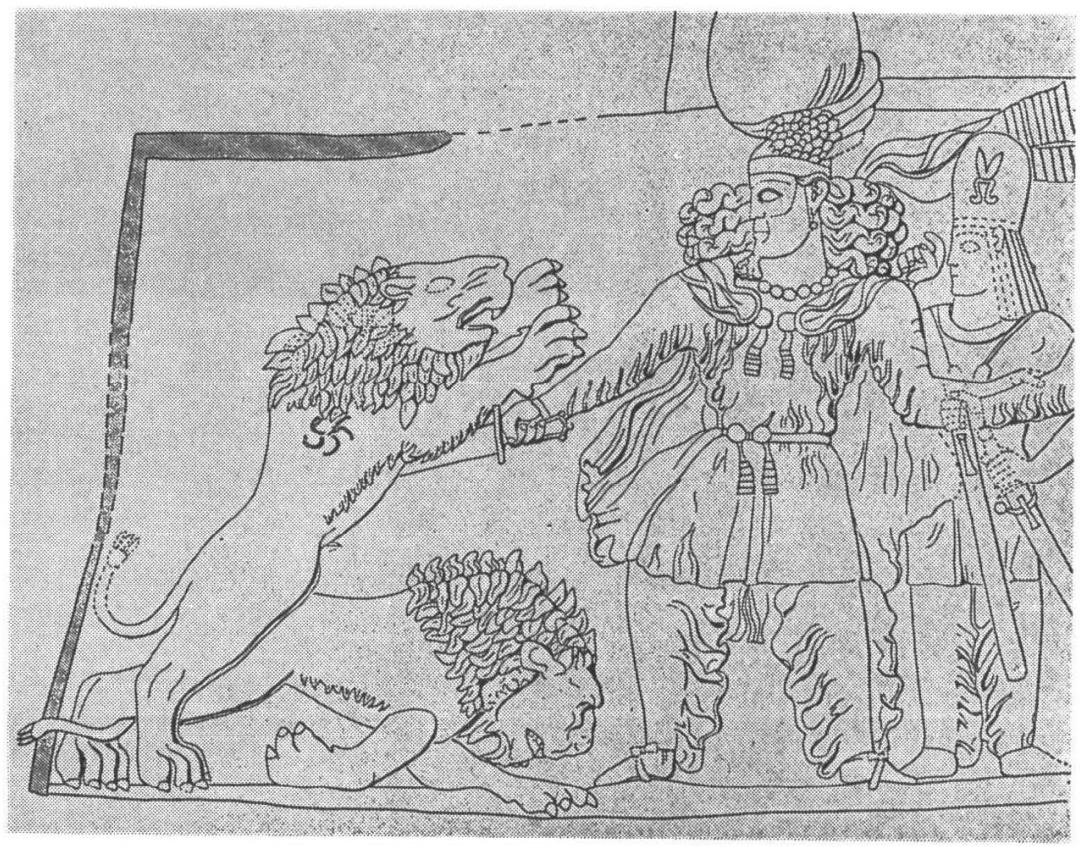

Fig. 17 Drawing of Sar Mašhad relief Trümpelmann 1975, Pl. 7 
the two lions represented in the royal hunt relief of Bahram II at Sar Mašhad in Southern Iran. The best picture of this relief was published by L. Trümpelmann. ${ }^{(57)}$ He published also the drawing of this relief, but the lion's shoulder ornament is not drawn in his drawing. However, if we look carefully at the picture, we can find out a shoulder ornamnent in the upper attacking lion (Fig. 16). Therefore, I added one shoulder ornament to his lion drawing (Fig. 17). Compared with the actual shoulder ornament attested in young lion cub illustrated by Bate(58) in the Journal of Near Eastern Studies, the shoulder ornament of the upper lion at Sar Mašhad proves to be in the correct position. Among the Royal Sasanian lion images this example is the only one hitherto attested. However, it is sure that this example was represented following faithfully the Royal Sasanian lion iconography of the third and probably early fourth centuries. Therefore, the shoulder ornament of the lions in the Sari plate (Fig. 8) is not of the Royal Sasanian workshop but rather of local or peripheral area. This assumption leads us to the conclusion that the Sari plate was not produced by Royal Sasanian workshop.

Next I would like to consider the lions of Gandharan sculpture. In Gandharan Buddhist sculpture, lions are quite often employed for the lionthrone. A few of these lions are decorated with one shoulder ornament (Fig. 18).(59) In addition to these some reliefs also include lions. These reliefs show two distinct types of rendering of lions. One type is decorated with a shoulder ornament and the other type with two shoulder ornaments, ${ }^{(60)}$ one on the shoulder and the other on the buttock (Fig. 19). The former seems to have been influenced by Parthian lion images.(61) A few silver rhytons recently discovered show a lion protome decorated with one shoulder ornament (Pl. II-a). Yet no Parthian lion image decorated with two shoulder ornaments has been discovered. Therefore the application of two shoulder ornaments to a lion seems to have been done by Gandharan sculptors who must have misunderstood this motif just as their Near Eastern predecessors mentioned above did. This misunderstanding, or intentional addition, might have occurred some time later, and surely after the tradition of depicting lions with one shoulder ornament was introduced in Gandhara and Kapisa. Therefore, I cannot agree with the dating of a toilet-tray on which is depicted an equestrian hunter attacking a lion with a hunting dog (Fig. 20). This unusual piece was first reported by S. Czuma(62) in 1985 at an exhibition of Kushan Sculpture. He dates this relic from the first century A. D., that is, the early Kushan period, 


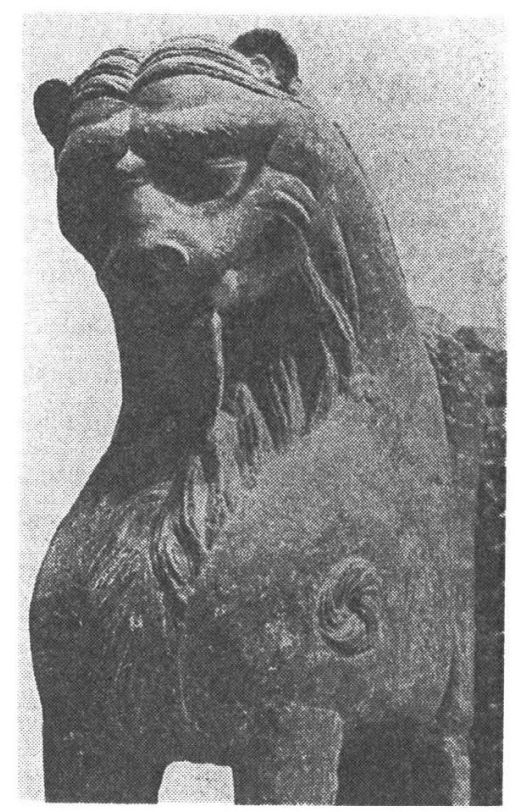

Fig. 18 Gandharan lion, Central Museum, Lahore The Mainichi Newspapers, 1961, Pl. 126

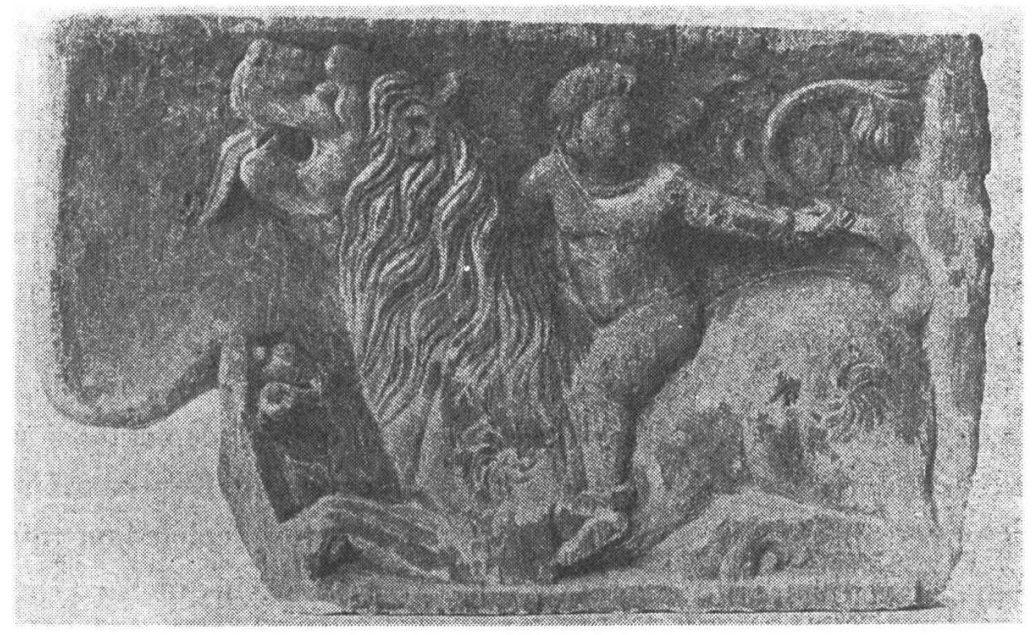

Fig. 19 Gandharan lion, Indian Museum, Calcutta Majumdar 1937, Pl. XI-b 


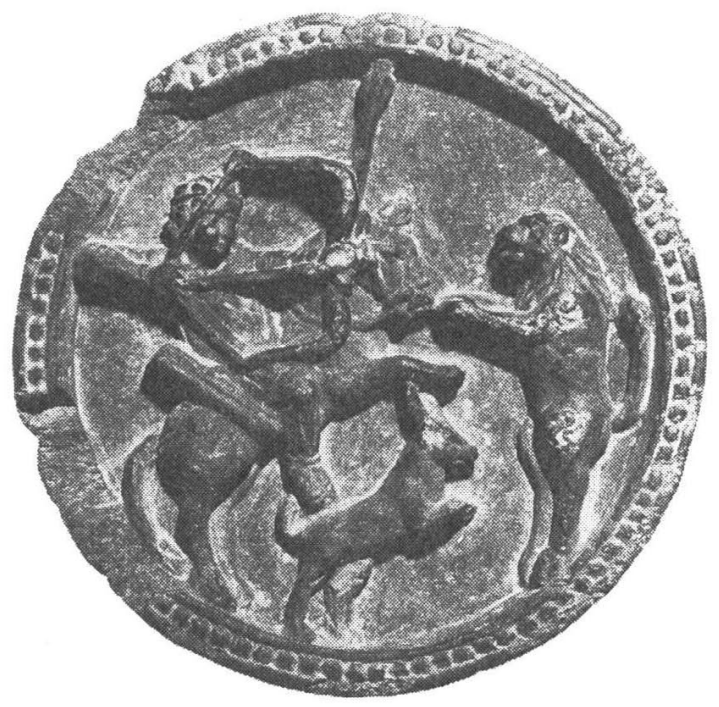

Fig. 20 Gandharan toilet-tray, Czuma 1985, Fig. 71

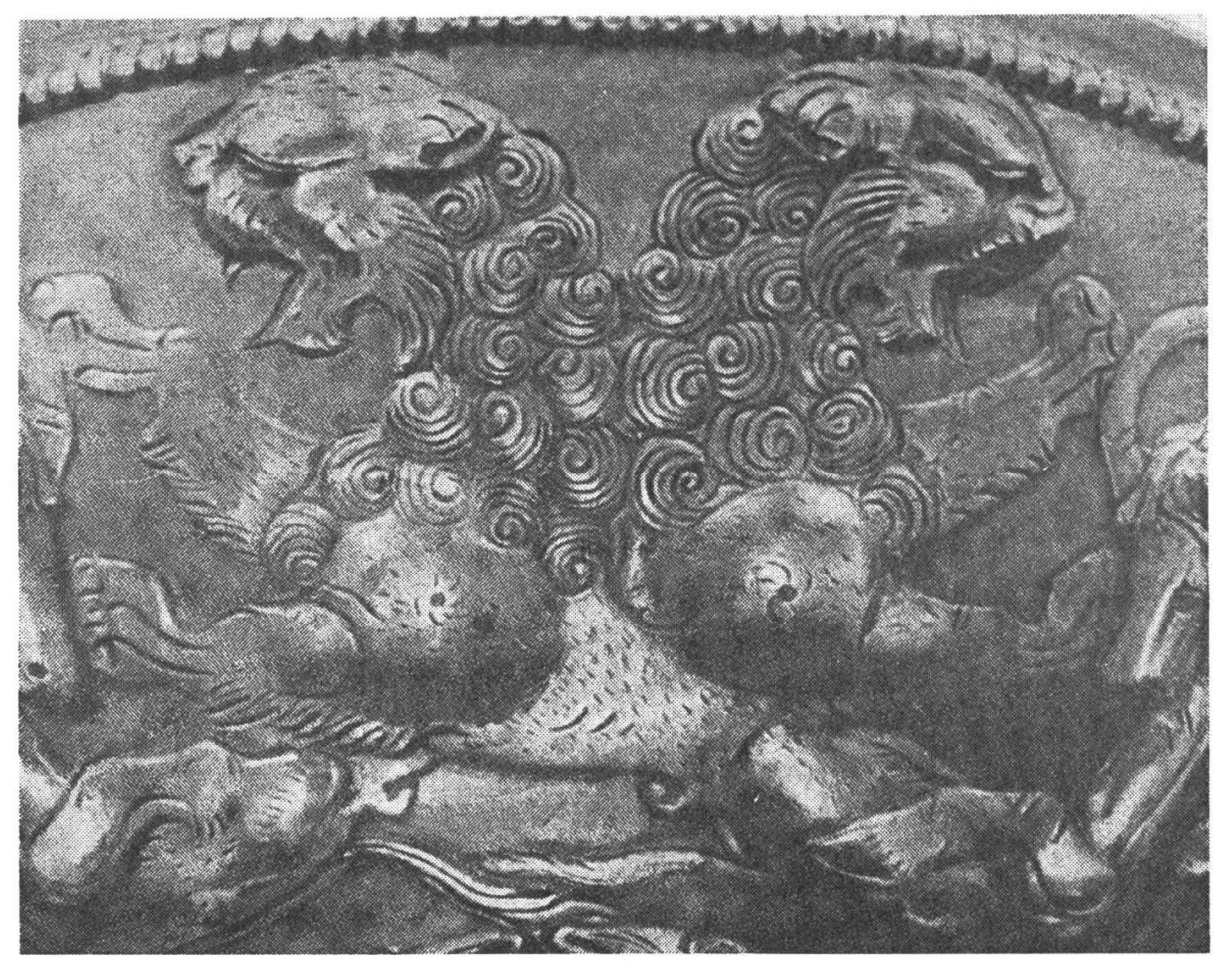

Fig. 21 Bactrian lion, silver bowl, Trever 1930, Pl. 23 
contemporary with the late Parthian period. However, the lion on this toilettray is decorated with two shoulder ornaments: one on the left shoulder, the other on the left buttock.

Lions are frequently represented in the toilet-trays ${ }^{(63)}$ unearthed in Gandhara, but no shoulder ornamentation has been reported except for that mentioned above. Most of these toilet-trays might have been produced from the second century B. C. to the first century A. D., but some could be of slightly later origin, i. e. in the Kushan period. Hellenistic (Fig. 21)(64) and Parthian lions are decorated with only a single shoulder ornament. Therefore, if that toilet-tray is genuine, the application of the two shoulder ornaments must have been later than those mentioned in Francfort's Catalogue (Indo-Greek and Indo-Parthian periods).

Furthermore there exists a unique bronze lion (Pl. II-b) ${ }^{(65)}$ with two shoulder ornaments. According to the owner, this was acquired in Kabul. In my opinion this lion should be dated from the late Kushan period or a little later, contemporary with the advent of the Sasanian and Kushano-Sasanian dynasties.

On the basis of these relics from Gandhara and adjacent regions, the two shoulder ornaments in the Sari plate (Fig. 8) seem to be intimately related to those of late Gandharan lions, i. e., of the third or early fourth century. The pointillé rendering of these shoulder ornaments is reminiscent of a similar rendering of a lion (leopard) protome (Pl. II-a) in the Parthian silver rhytons. This special technique also corroborates the earlier dating of the Sari plate.

\section{Irregular Parthian Shot Positioning}

One of the peculiarities of the Sari plate (Fig. 8) lies in the rendering of the Parthian shot. I am referring specifically to the irregular representation of the leg. R. Ghirshman ${ }^{(66)}$ also noticed this irregularity and suggested that this leg is not the left but the right one. If we accept Ghirshman's interpretation, the royal hunter in this plate must be sitting backwards on his horse, rather than in the so-called Parthian shot position. This interpretation was later accepted by A. D. H. Bivar and M. L. Carter. ${ }^{(67)}$ Their interpretations are based on the fact that the direction of the foot is contrary to that expected of the Parthian shot. However, I cannot completely agree with their interpretations. In my opinion, these three scholars have ignored the fact that 
Sasanians traditionally wore a long sword along the left leg and a quiver along the right. This fact is easily confirmed by Sasanian royal images in rock-cut reliefs and silver plates. Therefore, if the right leg were represented in this plate, the quiver would be shown rather than the sword we see. In Sasanian silver plates, the questrian royal hunters shooting arrows with compound-bows are always represented with their quivers on the right leg except for those cases in which they are in the Parthian shot position.

Therefore, there seems to have been a tradition of the quiver's being represented on the right leg and the sword's being worn on the left. The clumsy position of the left leg in the Sari plate can best be explained in the following way. The hunter's left leg is simply pointed backward at an extreme angle. A similar detail is attested by an equestrian hunter (Bahram V) depicted in a post-Sasanian silver plate of the Tenri Sankoukan Museum's collection(68) in Japan.

However, one factor does support Ghirshman's interpretation. It is the fact that while this hunter's trunk is twisted around backwards, the belt holding his sword does not reflect this movement at all. The belt holding the sword in place is loose, judging from its representation on Sasanian rock-cut reliefs and silver plates. Sometimes the Sasanians hold their swords along the vertical axis $^{(69)}$ of the body when standing on a field. The same representation is seen in the standing Kushan soldiers ${ }^{(70)}$ represented in Gandharan sculptures. Therefore, if a Kushan or Sasanian hunter on horse-back holding his sword by a loose belt twists his body quickly, his sword could remain on the left side of the horse's body and the turned right leg might be touching the sword. However, this is almost possible only from the theoretical viewpoint, and in actuality it would be almost impossible for the artist to imagine in that way. Furthermore, this kind of body-twisting is fairly acrobatic, and I am not sure whether such an acrobatic technique was available to the Sasanians and represented in artistic objects. At least the Sasanian equestrian hunt is not meant for exhibiting the Sasanian king's skill of acrobatic riding on horse, but rather for demonstrating his courageous and heroic fighting with fierce animals. Therefore, the artist who made this plate seems to have held little intention to represent such an acrobatic riding in this hunting scene. In my opinion, therefore, the prince in the Sari plate is not seated backward in the saddle, but in the irregular Parthian-shot position.

However, in this connection I should like to discuss a unique Gandharan 
relief( ${ }^{71)}$ showing a hunting scene (Pls. III, IV). In this relief, three hunters are riding horseback with their bodies facing backwards. Two of them are figthing a lion, one with a spear and the other by sword and shield. The third hunter is fighting a griffin with arrows and a compound-bow. However, the positioning of this third hunter is acrobatic rather than the traditional Parthian shot. He is distinctly shown being seated backward (Pl. IV). The facial features of this hunter seem to be Kushan. Taking into account the other two hunters' backward riding, the backward positioning of this hunter and that of the other two all seem to reflect actual representation. The continuous narrative or round perspective style of this relief seems to follow that of the hunting scenes depicted on many Roman sarcophagi or on some Hellenistic silver and ceramic bowls. Therefore, this acrobatic positioning might have derived from Roman or Hellenistic art which influenced the Buddhist art of Gandhara. However, as far as the present writer knows, no such positioning is attested by Roman and Hellenistic art relics. Thus at the present stage of our knowledge, it is not clear from whence this riding position derived, but the sculptor of this relief appears to have observed this style of riding. It would seem that this style of horseback riding was to some extent known in Gandhara and its adjacent regions. In any case, it is clear that this hunter's positioning is quite similar to the Parthian shot in the Sari plate. Therefore, the irregular Parthian shot of the latter might have some relation with the backward horseback riding of this Gandharan relief. More concretely speaking, it might be a mixture of the traditional Parthian shot and a backward horseback riding probably prevalent in Gandhara or adjacent regions. If my surmise is to the point, The artist of this plate attempted to adopt the Parthian shot for the upper body but the backward horseback riding for the left leg.

The Parthian shot is represented exactly in one ivory plaque excavated from Begram ${ }^{(72)}$ and a bone plaque excavated from Takht-i Sangin.(73) These two examples are dated to the Kushan period. On the other hand, The Parthian shot is represented exactly in the Sasanian silver plate unearthed from Shemakha( ${ }^{74)}$ dated to third or early fourth century.

\section{Concluding Remarks}

The iconographical, comparative investigations developed in this paper allow us to conclude that the Sari plate was produced in the region which was 
either influenced by Gandharan art or which could itself influence Gandharan art. This reasoning leads us to regard the place of its production as Afghanistan, probably southern Bactria (Kushano-Sasanian kingdom). It is true that the unique headdress of the hunter rendered here is reminiscent of that worn by Shahpur (?), son of Papak on a graffito at Persepolis, as P. O. Harper indicated. However, it does not necessarily follow that this plate was produced by the Royal Sasanian workshop, ${ }^{(75)}$ because it is possible that a certain son of Papak, a brother of Ardashir I may have been appointed as governor of the newly conquered province of Eastern Iran (Afghanistan).

Therefore I propose here to include the Sari plate into the group of the Kushano-Sasanian silver plates. The problem concerning the reasons why the style of this plate is different from those of the other four Kushano-Sasanian plates discussed in this paper, is fairly difficult and therefore is to be treated in my another paper. With regard to chronological sequence of these KushanoSasanian plates, it is not the purpose of this paper. However, here I would mention only that the Sari plate is earlier than other three and the latest is the Kabul plate. As for the Hermitage and Datong plates, the former seems to be earlier than the latter. This chronological sequence is nothing but my working hypothesis to be investigated in the future.

\section{Notes}

(1) B. Marshak, Sogdiiskoe Serebro, Moscow, 1971: Silverschatze des Orients, Leipzig, 1986, pp. 29-63. B. I. Marshak, Ya. K. Krikis, “Chilekskie chashi”, Trudy Gosudarstvennogo Ermitadja, X (1969), pp. 55-80. G. A. Pugachenkova, “Ob Epthalitskoi chashe iz Chileka”, (G. A. Koshelenko ed.) Problemy Antichnoi Kul'tury, Moscow, 1986, pp. 273-279.

(2) K. V. Trever, Pamyatniki Greko-baktriiskogo Iskusstva, Moscow/Leningrad, 1940. K. Weitzmann, "Three "Bactrian" Silver Vessels with Illustrations form Euripides", The Art Bulletin, XXV (1943), pp. 289-324, reprinted in K. Weitzmann, Classical Heritage in Byzantine and Near Eastern Art, London, 1981. B. I. Marshak, Ya. K. Krikis, op. cit., pp. 71-72: op. cit., 1986, pp. 38-39 (5-8 centuries) : B. Marshak, "Baktriiskie chashi”, (I. R. Pichikiyan ed.) Antichnost' $i$ antichnie Traditsii v Kul'ture i Iskusstve Narodov Sovetskogo Vostoka, Moscow, 1978, pp. 258-268 (3-7 centuries). Marshak's late dating of the Bactrian silver bowls is open to question.

( 3 ) O. M. Dalton, Treasure of the Oxus, London, 1964, Pl. XXXVIII-208. V. G. Lukonin, "Kushano-Sasanidskie Monety", Epigrafika Vostoka, XVIII, 1967, pp. 16-33, Fig. 6. P. O. Harper, Silver Vessels of the Sasanian Period, Volume 1: Royal Imagery, New York, 1981, Fig. 35.

(4) E. Herzfeld, Kushano-Sasanian Coins, Calcutta, 1930, Pl. I-3b, c, d, Fig. 21. V. G. Lukonin, op. cit., Fig. 3. R. Göbl, Münzprägung des Kuśānreiches, Wien, 1984, Taf. 114. M. L. Carter, "A Numismatic Reconstruction of Kushano-Sasanian History", Museum Notes, 30 (1986), pp. 215-281, Pl. 47-3. K. V. Trever, V. G. Lukonin, Sasanidskoe serebro sobranie Gosudarstvennogo Ermitadja, Moscow, 1987, Fig. 33.

( 5 ) P. O. Harper, op. cit., p. 108.

(6) K. Tanabe, "Date and Significance of the so-called Investiture of Ardashir II and the 
Images of Shahpur II and III at Taq-i Bustan", Orient, XXI (1985), pp. 102-121.

( 7 ) E. Herzfeld, op. cit., pp. 22-23.

(8) V. G. Lukonin, op. cit., 1967, p. 31.

(9) V. G. Lukonin, "Zavaevaniya Sasanidov na Vostoke i Problema Kushanskoi Absolytnoi Khronologii", Vestnik Drevnei Istorii, 1969, no. 2, pp. 20-44, reprinted in V. G. Lukonin, Drevnii i Rannesrednevekovyi Iran, Moscow, 1987, pp. 207-230.

(10) I. A. Orbeli, K. V. Trever, Sasanidskie Metall, Moscow, 1935, Pl. 4, p. XXXI.

(11) Ammianus Marcellinus, XIX, 1, 3 (Loeb Classical Library). The King himself, ..., wearing in place of a diadem a golden image of a ram's head set with precious stones, ....

(12) A. D. H. Bivar, "The Absolute Chronology of the Kushano-Sasanian Governors in Central Asia", (J. Harmatta ed.), Prolegomena to the Sources on the History of Pre-Islamic Central Asia, Budapest, 1979, pp. 327-328.

(13) Ch. Brunner, "The Chronology of the Sasanian Kushanshahs", Museum Notes, 19 (1974), p. 154 (Shahpur II). M. L. Cater, op. cit., p. 258, note 129. R. Göbl, op. cit., 1984, pp. 81, 84.; "Die Numismatik als Quelle zur Kunst der Sasaniden, der Kušān und der Iranischen Hunnen", Bulletin of the Asia Institute, I, 1987, pp. 66-69.

If we admit that a ram's head is different from a ram's horns, Bivar's identification is not tenable.

(14) R. Ghirshman, "Notes Iraniennes VI: Une Coupe Sassanide à scène de chasse", Artibus Asiae, XVIII (1955), pp. 5-19.

(15) Sh. Fukai, K. Horiuchi, Taq-i Bustan II, Tokyo, 1972, Pls. LXIV-LXXI. Sh. Fukai

et al., Taq-i Bustan III: Photogrammetric Elevations, Tokyo, 1983, Pls. XXV, XXVI.

(16) R. Ghirshman, Les Chionites-Hephtalites, MDAFA, t. XIII, Cario, 1948.

(17) E. Herzfeld, op. cit., Ch. Brunner, op. cit., pp. 161-162. M. I. Carter, op. cit., A. D. H. Bivar, op. cit., p. 332. J. Cribb, "Gandharan Hoards of Kushano-Sasanian and late Kushan Coppers", Coin Hoards, VI (1981), pp. 93-108.

(18) L. Bachhofer, "Sasanidische Jagdschalen", Pantheon, 1933, Heft 2, p. 1.

(19) K. Erdmann, "Die Sasanidische Jagdschalen", Jahrbuch der Preussischen Kunstsammelungen, 1936, pp. 198-199.

(20) Queen's crown decorated with ram's horns. Sardonyx seal of Bibliothèque Nationale. R. Curiel, Ph. Gignoux, "Sur une intaille sasanide du Cabinet des Médailles de Paris", Studia Iranica, t. 4, 1975, pp. 41-49. Ph. Gignoux, R. Gyselin, "Sceaux de femmes à l'époque sassanide", Archaeologia Iranica et Orientalis (ed. by L. de Meyer, E. Haerinck), Gent, 1989, pp. 882-884, P1. III-24.

A silver plate of the Waters Art Gallery. R. Ghirshman, Parthes et Sasanides, Paris, 1962, Fig. 295. The University of Michigan Museum of Art, Sasanian Silver, 1967, Fig. 13.

(21) P. O. Harper, op. cit., p. 37. B. Marshak, op. cit., 1986, pp. 26, 428 (after 388). K. V. Trever, V. G. Lukonin, op. cit., p. 108 (A. D. 390-420).

(22) P. O. Harper, op. cit., p. 73.

(23) P. O. Harper, op. cit., Pls. 25, 26.

The same kind of protome representation (of horses) is observed on a round plaque (bronze) excavated from Takht-i Sangin, Southern Tadjikistan. This is dated to 4-3 centuries B. C. by the excavator, but too early. State Hermitage Museum, Drevnosti Tadjikistan (exhibition catalogue), 1985, Fig. 219.

(24) M. M. Negro Ponzi, "Some Sasanian Moulds", Mesopotamia, II, 1967, p. 77.

(25) K. Erdmann, Die Kunst Irans zur Zeit der Sasaniden, Berlin, 1943, Taf. 65. Sasanian Silver, Fig. 4, p. 94 (Christos Bastis Collection). P. O. Harper, op. cit., Pl. 20. B. Genito, "Su un piatto d' argento di tradizione sasanide in una collezione privata americana", Annali, 38 (1978), pp. 155-168, Pl. I.

The silver plate of Museum für Islamische Kunst, Staatliche Museen Preussicher Kulturbesitz, Berlin, should be dated to Post-Sasanian period. Another piece of Christos Bastis Collection seems to be modern fake. 
(26) P. O. Harper, op. cit., p. 73.

(27) P. O. Harper, op. cit., p. 74.

(28) P. O. Harper, op. cit., pp. 146-158.

(29) G. Herrmann, The Sasanian Rock Reliefs at Bishapur: Part 2, Berlin 1981, Fig. 2, Pl. 9.

(30) G. Herrmann, ibidem, Fig. 1, Pl. 2. L. Trümpelmann, Das sasanidische Felsrelief von Sar Mašhad, Berlin, 1975, Taf. 5. G. Herrmann, The Sasanian Rock Reliefs at Bishapur: Part 3, Berlin, 1983, Pl. 26, Fig. 3.

(31) G. Herrmann, Naqsh-i Rustam 5 and 8, Sasanian Reliefs attributed to Hormuzd II and Narseh, Berlin, 1977, Fig. 2. Pl. 10.

(32) L. Trümpelmann, Das Sasanidische Felsrelief von Darab, Berlin, 1976, Taf. 1, 9. G. Herrmann, The Sasanian Rock Reliefs at Bishapur: Part 1, Berlin, 1980, Text Fig. 1 (p. 34, reconstruction of Shahpur I).

(33) Sh. Fukai, K. Horiuchi, op. cit., Pls. LXIVff. Sh. Fukai et al., op. cit., 1984, Pls. XXII, XXIII, XXV, XXVI.

(34) G. Herrmann, op. cit., 1977, Pls. 8, 9, 10, Fig. 2.

(35) F. Grenet, "Un plat sasanide d' Ardashir II (379-383) au bazar de Kabul", Studia Iranica, 12 (1983), pp. 195-204.

(36) Ma Yuji, "Excavation of the Northern Wei Tomb at Huagedatai in Xiaozhancun, City of Datong”, Wenwu, No. 8, 1983, pp. 1-4. Xia Nai, "A Sasanian Silver Plate from the Tomb of Feng Hetu of the Northern Wei Dynasty", ibidem, pp. 5-7. Ma Yong, "Notes on the Northern Wei Dynasty Tomb of Feng Hetu and the Persian Silver Plate Unearthed", ibidem, pp. 8-12.

(37) K. Tanabe, op. cit., Fig. 1. P. O. Harper, "A Kushano-Sasanian Silver Bowl”, Archaeologia Iranica et Orientalis, Gent, 1989, p. 859.

(38) Ma Yuji, op. cit., p. 3. Xia Nai, op. cit., p. 5. Ma Yong, op. cit., p. 8.

(39) According to the description of $M a$ Yong, above, note 36, p. 9, there is one horn-like projecting ornament in front of and above helmet (其頂上前端有一突起之角状飾). However, if we look at both print and picture of this plate published in $W e n W u$, this projecting ornament seems to be composed of two bulbous ornaments.

(40) P. Calmeyer, "Zur Genese altiranischer Motive: V. Synarchie", Archaeologische Mitteilungen aus Iran, N. F. 9 (1976), pp. 63-95, Fig. 4. P. O. Harper, op. cit., 1981, p. 55, Fig. 19, Pls. 8 (silver plate from Shemakha), 10 (silver plate from Sari). V. G. Lukonin, Iran $v$ epokhu pervykh Sasanidov, Leningrad, 1961, Fig. 1.

(41) P. O. Harper, op. cit., 1989, pp. 845-860, Pls. 1-III.

(42) R. Ghirshman, op. cit., 1955, p. 5. L. Vanden Berghe, L'Archéologie de l'Iran Ancien, Leiden, 1959, p. 6, Pl. 7-a.

(43) P. O. Harper. op. cit., 1981, p. $126 . \quad$ K. V. Trever, V. G. Lukonin, op. cit., p. $54 . \quad$ B. Marshak, op. cit., 1986, pp. 24-25. M. L. Carter, op. cit., p. 232.

Carter mentions that the headdress of the prince of this plate is similar to those of the KushanoSasanian kings. Although the headdress is not identical with any of the crowns of the KushanoSasanian kings, the general idea of making headdress or crown seems to be common to both as was observed by Carter.

(44) R. Ghirshman, op. cit., 1955, p. 9.

(45) H. J. Kantor, "The Shoulder Ornament of Near Eastern Lions", Journal of Near Eastern Studies, VI (1947), pp. 250-274. J. B. W. Perkins, "The Bronze Lion of St. Mark at Venice", Antiquity, 21 (1947), pp. 23-41. A. Voligraff-Rose, "The Lion with Body Markings in Oriental Art", JNES, 12 (1953), pp. 40-49. The Metropolitan Museum of Art, Treasures of the Holy Land, New York, 1986, Pl. 44.

(46) E. R. Goodenough, Jewish Symbols in the Greco-Roman Period, Vol. 7, New York, 1958, Fig. 37 (Archaeological Museum, Istanbul).

(47) A. Godard, Les trésors de Ziwiyé (Kurdistan), Paris, 1950, Fig. 16, 17. L. Vanden Berghe, op. cit., Pl. 2-a (Kalār Dasht), 140-a. With regard to the ornamentation of the lions depicted 
in the Kalar Dasht plate, it should be mentioned that two svastikas are engraved on the buttock and head. In this case, svastikas seem to be abbreviated shoulder ornaments employed as simple ornaments or emblem of the sun, because their shape is quite similar to the shoulder ornament engraved on the foreleg. A svastika is engraved also on the buttock of a lion depicted on the gold bowl excavated at Hasanlu. E. Porada, The Art of Ancient Iran, New York, 1965, Figs. 63, 64. M. J. Mellink, "The Hasanlu Bowl in Anatolian Perspective", Iranica Antiqua, 6(1966), pp. 73-87, Text-fig. 1b. Comte R. du Mesnil du Buisson, "Le mythe oriental des deux géants du jour et de la nuit", ibidem, 8 (1968), pp. 1-33, Fig. 9.

(48) R. D. Barnett, A. Lorenzini, Assyrische Skulpturen in the British Museum, Toronto, 1975, Figs. 32, 33 (Assurnasirpal II, Nimrud), 130 (Assurbanipal, Niniveh). A. Lorenzini, Gli Assiri, Roma, 1980, Pls. 17a, c, 53.

(49) A. J. Arkell, “The Shoulder Ornament of Near Eastern Lion", Journal of Near Eastern Studies, 7 (1948), p. 52. D. M. A. Bate, "The Shoulder Ornament of Near Eastern Lions", ibidem, 9 (1950), pp. 53-54, Pl. II.

(50) P. Amiet, "Autour de Marlik", Archaeologia Iranica et Orientalis, 1989, pp. 311-322, Fig. 1. P. Diba, Les Trésors de l'Iran et le vase en or des Mannéens, Paris, 1965, Figs. 20, 21a, 38, 62a. Cf. literature quoted in note 47 above.

(51) P. O. Harper, op. cit., 1981, Pls. 11a, b, 14, 20, 25, 30, 37.

(52) K. Erdmann, Die Kunst Irans zur Zeit der Sasaniden, Berlin, 1943, Taf. 76. V. P. Darkevich, Khudodjestvennyi Metall Vostoka, Moscow, 1976, Figs. 3, 4, 6, 7. K. V. Trever, V. G. Lukonin, Sasanidskoe serebro sobranie Gosudarstvennogo Ermitadja, Moscow, 1987, Pls. 114, 115.

(53) A. M. Belenizki, Mittelasien, Kunst der Sogden, Leipzig, 1980, Taf. 69, 70, 73-76. B. A. Litvinskii, V.S. Solov' ev, Srednevekovaya Kul'tura Tokharistana, Moscow, 1985, Fig. 19, p. 118. Museum Rietberg Zürich, Oxus, 2000 Jahre Kunst am Oxus-Fluss in Mittelasien, 1989, p. 88, Taf. 50.

(54) K. V. Trever, V. G. Lukonin, op. cit., Pl. 114. V. P. Darkevich, op. cit., p. 19, interprets this as rosette, symbol of sun, solar symbol.

(55) D. A. Khalilov, K. O. Koshkarly, "Ikonografiya dvukh serebryanykh blyud iz Azerbaidjana", V. G. lukonin (ed.), Khudodjestvennye pamyatniki i problemy kul' tury Vostoka, Leningrad, 1985, pp. 77-81, Fig. 2.

(56) O. von Falke, Kunstgeschichte der Seidenweberei, Berlin, 1921, Taf. IV, Abb. 25, 99, 103-

106. E. Kühnel, Islamische Kleinkunst, Braunschweig, 1963, Fig. 125.

(57) L. Trümpelmann, Das Sasanidische Felsrelief von Sar Mašhad, Berlin, 1975. Taf. 1, 2, 7 (drawing).

(58) D. M. A. Bate, op. cit., Pl. II.

(59) J. Meunié, Shotorak, MDAFA, t. X, Paris, 1942, Pl. XXXV-113. The Mainichi Newspapers, Ancient Pakistan Culture Exhibition, Tokyo, 1961, Pl. 126 (excavated from Sanghao, Central Museum, Lahore).

(60) H. Ingholt, Gandharan Art in Pakistan, New York, 1957, Fig. 454. N. G. Majumdar, A Guide to the Sculptures in the Indian Museum, Part II, The Graeco-Buddhist School of Gandhara, Delhi, 1937, Pl. XI-b.

(61) Th. Lawton et al., Asian Art in the Arthur M. Sackler Gallery, Washington, 1978, Figs. 17, 18. Parthian lion hunts are depicted in a rock-cut relief and two graffiti but the shoulder ornament cannot be attested by the lion images of these examples due to their inferior preservation. Cf. M. I. Rostovtzeff, "Dura and Problem of Parthian Art", Yale Classical Studies, V (1935), pp. 157-304, Figs. 56, 85 (Dura Europos). L. Vanden Berghe, K. Schippmann, Les Reliefs Rupestres d'Elymaide (Iran) de l'Epoque Parthe, Gent, 1985, Fig. 11, P1. 45. T. S. Kawami, Monumental Art of the Parthian Period in Iran, Leiden, 1987, Fig. 17, Pl. 40.

(62) S. Czuma, Kushan Sculpture: Images from Early India, Cleveland, 1985, Fig. 71, p. 153.

(63) H.-P. Francfort, Les Palettes du Gandhara, MDAFA, t. XXIII, Paris, 1979, Nos. 22, 48, $71,72,73,84,85,86$. 
(64) K. V. Trever, op. cit., Pl. 23.

(65) S. Mizuno, "Bronze Buddhist Seated Images in Small Size from Kashmir, Swat and Kabul", Ars Buddhica, 78 (1970), pp. 50-53, Fig. 5. In Japanese.

(66) R. Ghirshman, op. cit., 1955, p. 7. However, he changed his interpretation later and regarded this position as Parthian shot. R. Ghirshman et al., Persia, The Immortal Kingdom, New York, 1971, p. 70.

(67) A. D. H. Bivar, "Cavalry Equipment and Tactics on Euphrates", Dumbarton Oaks Paper, 26 (1972), p. 285 (seated backward in the saddle). M. L. Carter, op. cit., p. 232 (seated backward).

(68) K. Tanabe, "A Sasanian Silver Plate with a Leopard Hunt”, Bulletin of the Asia Institute, 1 (1987), pp. 81-94, Figs. 1, 5.

(69) W. Trousdale, The Long Sword and Scabbard Slide in Asia, Washington, 1975, Figs. 67-78.

(70) W. Trousdale, ibidem, Figs. 49-56.

(71) This unique relief was already published by the present author. K. Tanabe, Unique Gandharan reliefs with Equestrian Hunting Scene, Supplement to the Bulletin of the Ancient Orient Museum, vol. V (1983), Pls. I-II. In Japanese with English summary.

(72) J. Hackin et al., Nouvelles recherches archéologiques à Begram, Paris, 1954, Planches, Fig. 112.

(73) B. A. Litvinsky, I. R. Pichikiyan, "Temple of the Oxus", Journal of the Royal Asiatic Society of Great Britain and Ireland, 1981, no. 2, pp. 133-167, Pl. VII: "Découvertes archéologiques dans un sanctuaire du dieu Oxus de la Bactriane septentrional”, Revue Archéologique, 1981, fasc. 2, pp. 195-216, Figs. 15-16.

(74) P. O. Harper, op. cit., 1981, PI. 8. V. G. Lukonin, Iran v III veke, Moscow, 1979, Fig. 26.

(75) Harper regarded the royal prince of the Sari Plate as crown prince of Sasanian empire and ruler of Gilan province, because it was found in northern Iran (actually Mazandaran province). However, the provenance of the plate does not necessarily mean the place of production. P. O. Harper, op. cit., pp. 56, 126. 

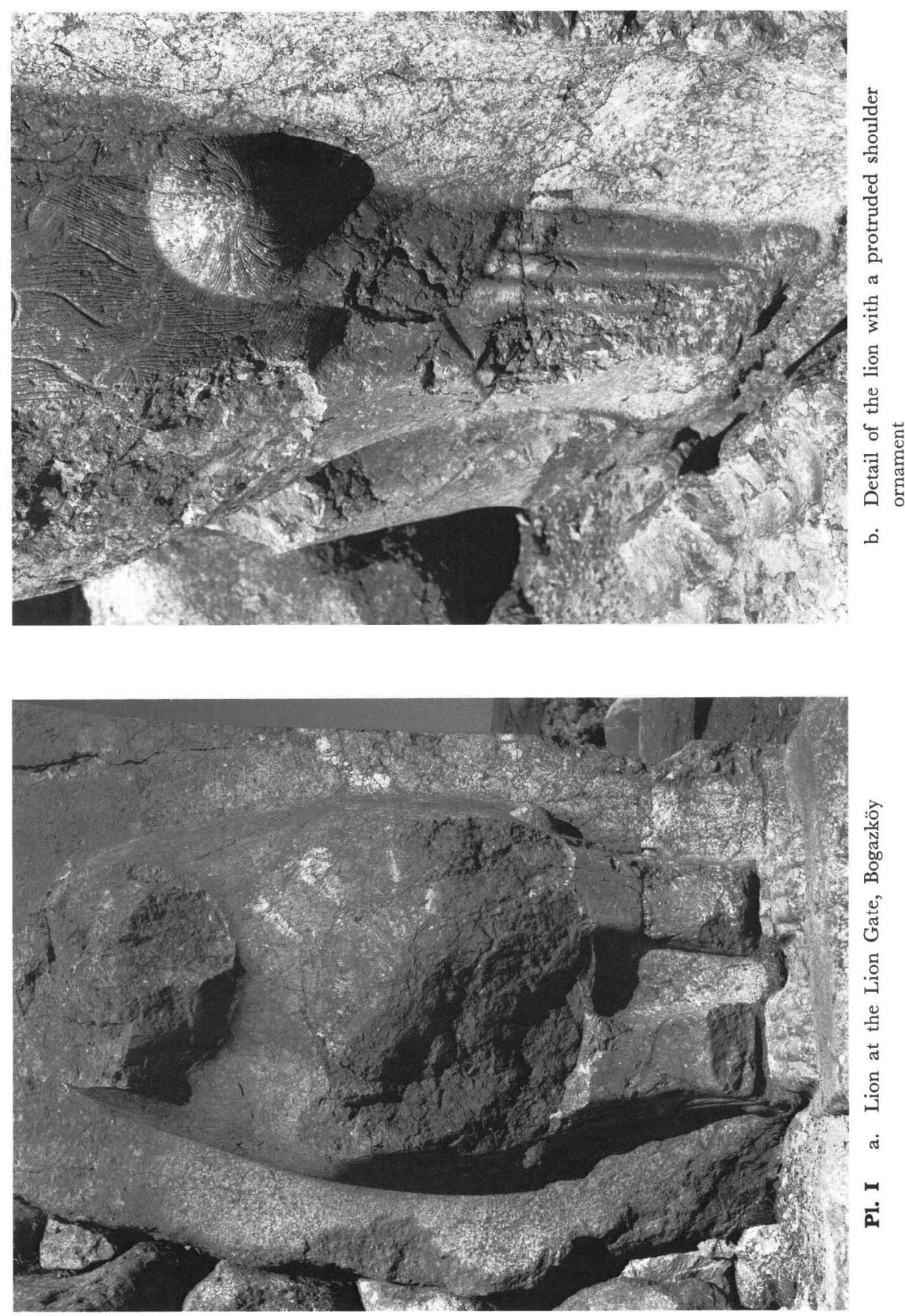

Vol. XXV 1989 
P1. II

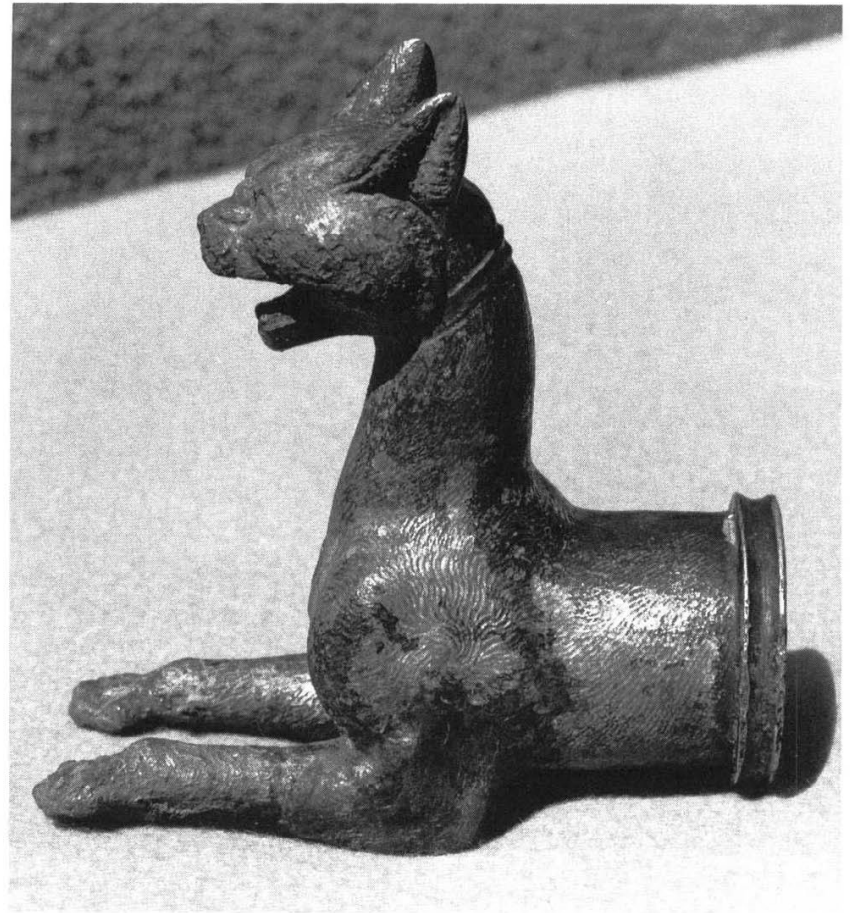

a. Protome of lion (leopard), silver rhyton, private collection, Osaka

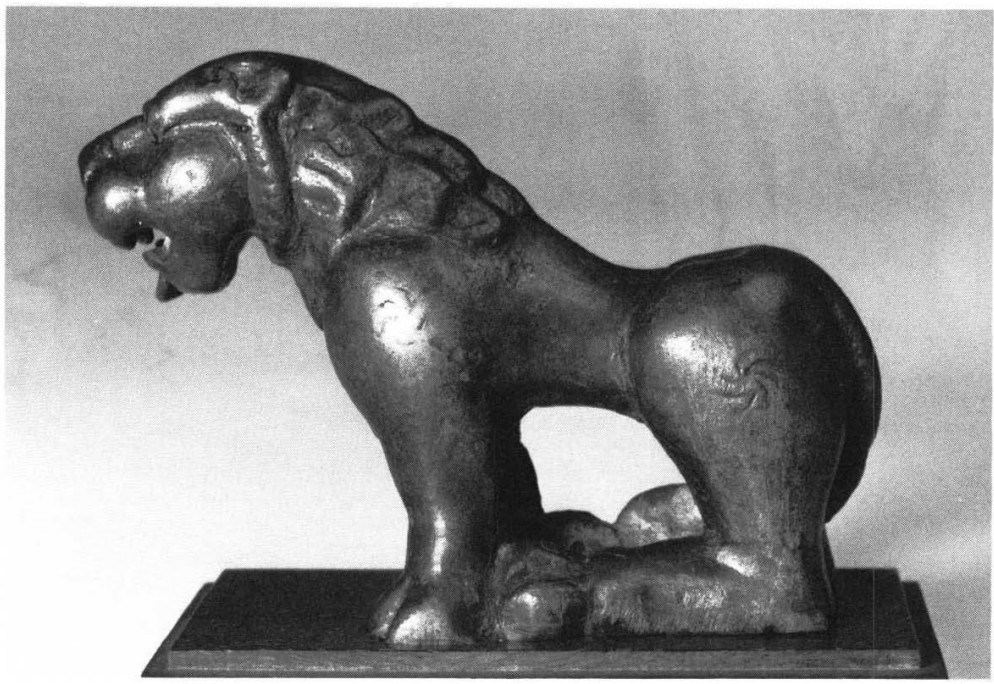

b. Bronze lion, Mr. and Mrs. Ishiguro collection, Tokyo 


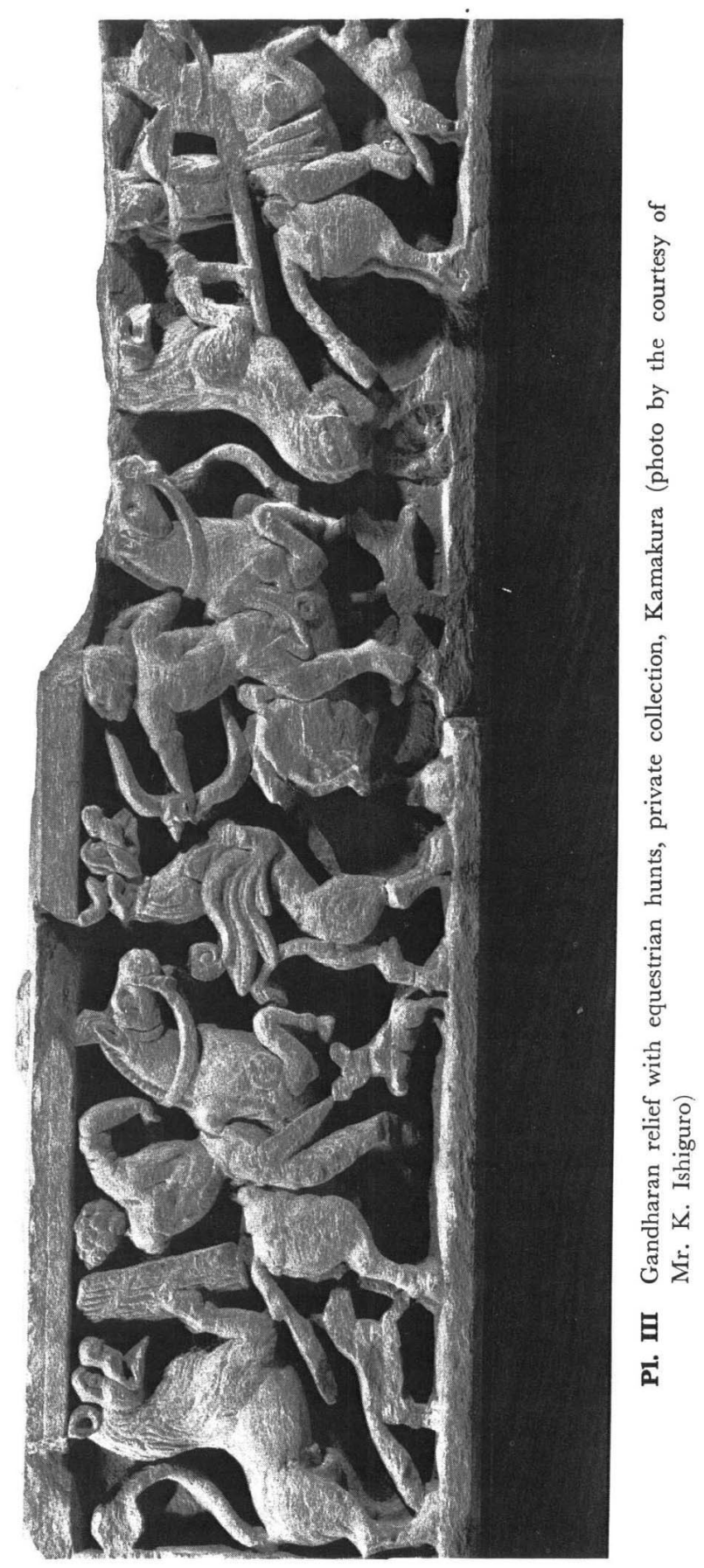




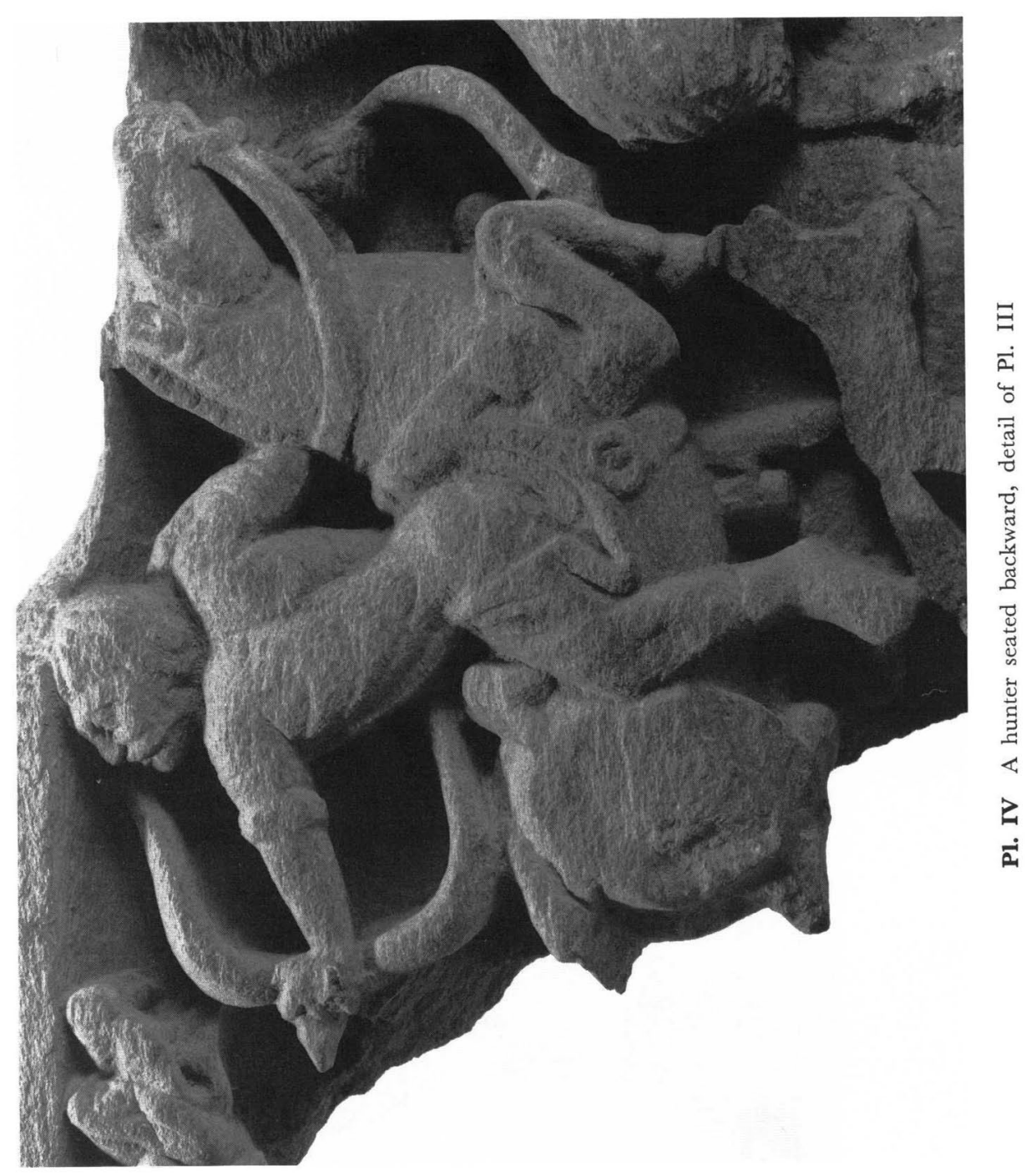

